\title{
A tehetséges fiatalok segitése a felsőoktatásban a pszichológiai tanácsadás módszertanával
}

\author{
Molnár, Edina: \\ Facilitate for Talented Students in Higher Education by Counceling Psychology Methodology
}

Personality development and learning support are the fields of the psychological counselling, which can help to every student in the higher education, and are particularly important for the talented young people. The unfolding of the genius means the complex development of the personality, the exploration and the conscious and directional development of the strengths and weaknesses. This is not a trouble free process and it is also not a simply task to take on the external viewer position. The counsellor can help to the students and can produce the chance for the development to the genius young people with the method of the personality development and the learning support.

Keywords: talent support, psychological counselling, higher education, personality development, learning support

\section{ÖsSZEFoglató}

A személyiségfejlesztés és a tanulástámogatás a pszichológiai tanácsadás olyan területei, amelyek minden felsőoktatásban részt vevő hallgató számára segítséget nyújthatnak, de különösen fontosak a tehetséges fiatalok esetében. A tehetség kibontakoztatása a személyiség komplex fejlesztését jelenti, az erősségek és a gyengeségek feltárását és azok tudatos és irányított fejlesztését, amely azonban nem mindig problémamentes és nem könnyű feladat a fejlesztéshez szükséges külső szemlélő pozíciójának felvétele sem. Ebben nyújt segítséget a tanácsadó, aki a személyiségfejlesztés és a tanulástámogatás módszertanával a tehetséges fiatal számára megteremti a fejlődés lehetőségét.

Kulcsszavak: tehetségsegítés, pszichológiai tanácsadás, felsőoktatás, személyiségfejlesztés, tanulástámogatás

\section{Bevezetés}

Napjainkban egyre nagyobb szerepet kap a tehetséges fiatalok felkarolása, menedzselése, személyiségük komplex kibontakoztatási lehetőségének megteremtésén keresztül. A felsőoktatásban működő pszichológiai, életvezetési tanácsadás módszertana a személyiség teljes fejlesztésére, a problémák kezelésére, a tanulás támogatására irányul. Ezen tevékenységek alapját képezik a felsőoktatásban zajló tehetségsegítésnek is.

\section{SZEMÉLYISÉGFEJLESZTÉS}

\subsection{A counselling tevékenység}

A counselling szó jelentése: tanácsadás, tanácskozás, bölcselkedés, konzultáció. Magyarországon a tanácsadás, a tanácsadó pszichológus kifejezések terjedtek el. Tanácsadásnak nevezünk minden olyan emberek közötti interakciót, amely a másik ember segítésére szolgál. A mindennapi életben az érzelmi problémák öt nehézségi fok szerint különbözhetnek, mind az öt nehézségi fokhoz vagy szinthez a tanácsadónak a megfelelő módon kell viszonyulnia.

Az első szinten a normális életben előforduló problémák, így például a bizonytalanság érzései helyezkednek el. Ebben az esetben a 
tanácsadó feladata az útmutatás, amely nem feltétlenül pszichológiai jellegű. Ezen a szinten mindannyian végezzük a tanácsadás tevékenységét, például amikor egy barátnővel megbeszéljük - „kibeszéljük” - a férjével kapcsolatos aggodalmait.

A második szinten a döntéshozatali problémák állnak, ebben a helyzetben a tanácsadó szerepe a megerősítés. Segítséget nyújthat a célok kitűzésében, a helyzet tisztázásában. Ezen a szinten a tanácsadó - aki nem feltétlenül pszichológus - részéről a problémának egy külső szemszögből történő vizsgálata szükséges.

A harmadik szinten a belső konfliktusok állnak, amelyek a bizonytalan jövőtől való félelemben nyilvánulnak meg. A tanácskérő életében a valóság és az igényei között nincs megfelelés, a tanácsadó feladata - aki ezen a szinten már szakember - a feszültségcsökkentés, a kompromisszum megtalálásának elősegítése a reális és az ideális között.

A negyedik szinten mélyebb érzelmi problémák merülhetnek fel, amelyeknek a megoldása már elképzelhető, hogy túlmutat egy tanácsadás keretein, ebben az esetben valamilyen típusú terápia ajánlott, a tanácsadó feladata tehát az, hogy a tanácskérőt terapeutához irányítsa.

Az ötödik szinten a tanácskérőt nagymértékü integrációhiány jellemzi, a valóságba való beilleszkedés teljes képtelensége. Ehhez a szinthez organikus eredetű pszichés betegségek társulhatnak, amelyeket kizárólag megfelelő szakember kezelhet.

A counselling tevékenységet többféleképpen rendszerezhetjük. A tanácsadás jellege szerint lehet kurativ, preventiv, illetve optimalizációs.

A kuratív tanácsadás a legősibb a többi között, egy meglévő probléma helyreállítására törekszik. A kuratív - gondozáson alapuló - tanácsadás a tanácskérő aktivitására épül, hiszen a tanácskérő feladata, hogy kijelölje és felkeresse a tanácsadót, a tanácsadó pedig gondoskodik a probléma megoldásáról.

A preventív tanácsadás célja, hogy szakmai segítséget nyújtson a potenciális problémák megelőzésében. Nagy szerepe lehet például egy iskola vagy egy cég szervezetének, kommuniká- ciós viszonyainak megtervezésében, vagy például egy megfelelő pályaválasztási tanácsadás megelőzhet egy esetleges ifjúkori válságot.

Az optimalizációs tanácsadás adott helyzeteket harmonizál, kompromisszumokat keres, a tanácskérő számára a lehető legjobb megoldást próbálja megtalálni az egymással összeegyeztethetetlennek tűnő szituációkban.

A tanácsadó tevékenység tartalma alapján is rendszerezhető, amely szerint megkülönböztethető az összefoglaló, illetve a speciális tanácsadás.

Az összefoglaló tanácsadás segíti feltárni a tanácskérő olyan jellegzetességeit, amelyek az élet minden területén problémaforrást jelentenek. Tulajdonképpen életvezetési tanácsadásként lehet ezt a tevékenységet koncipiálni, amely a felnőttkori típushibákat igyekszik feltárni és megoldani.

A speciális tanácsadás már nem terjed ki az élet minden részletére vagy minden életszakaszra az életkor tekintetében, hanem egy valamilyen szempontból körülhatárolható területet ölel fel. Így például beszélhetünk nevelési tanácsadásról, amely a gyermekkor tipikus nevelési problémáit igyekszik orvosolni, vagy pályaválasztási tanácsadásról, amely a serdülőkor tipikus identitáskeresési, illetve az ezzel összefüggő hivatáskeresési problémákat állítja a középpontba. Tematikusan a pályaválasztáshoz kapcsolódóan, de kilépve a serdülőkorból karrier-tanácsadásként, munkavállalási tanácsadásként, illetve munkanélküli tanácsadás formájában is felbukkanhatnak az egy tőről fakadó problémák megoldástörekvései.

A munkával kapcsolatos problémák mellett a családi, magánéleti problémák megoldására például a párválasztási, a házassági, illetve a családi tanácsadást említhetjük, amelyek a tanácskérő informális kapcsolatainak rendezésére vállalkoznak.

$\mathrm{Az}$ informális kapcsolatok mellett az ember életében természetesen a formális kapcsolatok is teret kapnak, amelyekkel például a szervezeti tanácsadás foglalkozik, vagyis egy cégen belüli, például a főnök-beosztott viszonyon alapuló konfliktusok feloldására vállalkozik. 
A tanácsadói tevékenység forma szerinti csoportosításban is értelmezhető, a tanácskérő és a tanácsadó kapcsolatának különböző formáit alapul véve.

A tanácsadó és a tanácskérő közötti legrégebbi kapcsolati forma az egyéni tanácsadás, amikor a tanácskérő egy előre megbeszélt időpontban egyedül keresi fel a tanácsadót, és ketten próbálnak a tanácskérő problémáira megoldást találni.

Szintén elterjedt forma a csoportos tanácsadás, amelynek során hasonló problémákkal küszködő emberek egymással és szakemberekkel beszélgetnek. Ez a forma a tanácskérőkben az arról való tudást erősíti, hogy nincsenek egyedül a problémáikkal, hogy ezek a problémák más emberekben is feszültséget okoznak, és hogy ezt a feszültséget, a kellemetlen állapotot fel lehet oldani.

Nem olyan régi forma a kortárs tanácsadás, amely hasonló korúak egymásnak nyújtott segítségét jelenti, és ahol a tanácskérőben az az érzés erősödik, hogy nem különbözik a kortársaitól, mert őket is hasonló problémák foglalkoztatják.

Végül az úgynevezett „cocounselling” sorolható a kapcsolati formák negyedik típusába, amelyben a tanácsadó és tanácskérő szerepek kölcsönös felcserélődése következik be, például két szakember kapcsolatában, akik egymás szupervízorai lehetnek.

A tanácsadás tevékenységét az alkalmazott módszerek szerint direktív és non-direktív csoportokra oszthatjuk.

A direktív tanácsadás információt, irányítást ad a tanácskérőnek, egyértelműen alá-, fölérendeltségi viszonyon alapszik. A tanácsadó a tudás magasabb fokán állva tanácsot ad a tanácskérőnek, aki valóban el is várja, hogy a problémára, amivel odafordult a tanácsadóhoz, határozott megoldást kapjon.

A non-direktív tanácsadás - és a magyar megnevezés ezért nem igazán jó - nem ad a szó szoros értelmében vett tanácsot, hanem a tanácskérő önálló, saját erejü munkájára építve az utat mutatja meg a megoldáshoz. A tanácsadás végére a tanácskérő azt érzi, hogy ő saját maga oldotta meg a problémáját, ezáltal a megoldást a sajátjának, belülről fakadónak tekinti, és nem egy más személy által ráerőltetettnek.

Az eddig elmondottakból kiindulva a tanácsadási beavatkozások hat kategóriáját különböztethetjük meg. Az első kategória az utasító tanácsadás, amelynek célja az irányítás. A második kategória az informatív tanácsadás, amely az információnyújtáson alapul. A harmadik kategória a konfrontáló tanácsadás, amely a tanácskérőt megpróbálja ráébreszteni egy másfajta viselkedésre. A negyedik beavatkozási lehetőség a katartikus tanácsadás, amely az érzelmek lereagálására épít. Az ötödik kategória a katalizáló tanácsadás, amely a problémamegoldást mozdítja előre. Végül a hatodik kategória a támogató, amely megerősítést ad a tanácskérőnek.

A tanácsadó a counselling tevékenység során a problémák feltárására törekszik, majd a probléma függvényében, valamint a tanácskérő életkori és pszichológiai jellemzőit szem előtt tartva kiválasztja a megfelelő módszert, amely természetesen a tanácsadás alatt megváltozhat, illetve egyszerre több módszer is alkalmazható.

A szakszerü tanácsadó tevékenysége a következő 11 pontban foglalható össze:

- A segítés céljai

- Segíteni próbál a tanácskérőnek céljai elérésében

- Hajlandó bizonyos esetekben alternatív felfogásmódokat ajánlani és irányt mutatni

- Igazodik a tanácskérő stílusához

- Válaszok kialakítása

- Képes a szituációk és problémák széles skálájához sokféle válaszmegoldást nyújtani

- Nem ragaszkodik tipikus válaszmódokhoz 
- Világszemlélet

- Sokféle világszemléletet megért és elfogad

- Elméletek alkalmazása

- Megért és használ különböző elméleti irányzatokat

- Rétegek (szubkultúrák) közötti átjárhatóság

- Maximális számú verbális és nem verbális mondat alkotására képes a szubkultúrák közötti kapcsolat megteremtése érdekében

- Nem ragaszkodik mereven a saját kultúrképéhez

- Titoktartás

- Kizárólag a tanácskérő engedélyével beszél a tanácsadásról másoknak

- Korlátok

- Ismeri saját korlátait

- Tapasztaltabb tanácsadó segítségét kéri, ha szüksége van rá

- Információgyűjtés

- Fontosnak tartja a tanácskérő gondolatait, érzésit

- Nem vész el a részletekben, a lényegre koncentrál

- Személyközi befolyás

- Tisztában van vele, hogy hogyan befolyásolja válaszával a tanácskérőt, illetve, hogy a tanácskérő milyen hatást vált ki benne

- Emberi méltóság

- Tiszteletet és megbecsülést tanúsít a tanácskérő iránt

- Fejlődési lehetőség

- Aktívan vizsgálja saját énjét és világszemléletét

- Folyamatosan új elméleteket sajátít el

- Kialakítja saját módszerét

\subsection{Counselling a felsőoktatásban}

Felsőoktatási hallgatói tanácsadói szolgáltatások az USA főiskoláin és egyetemein már az 1930-as évek elejétől léteznek. 1930-ban a Minnesota Egyetemről indult fejlődésnek az ún. „hallgatói személyzeti szempontot" megfogal- mazó törekvés, amely a hallgatóknak nyújtott ismeretanyag mellett a hallgatók egyéb igényeit is figyelembe véve igyekezett minél szélesebb körü tájékoztatást adni. Majd az 1970-es évektől a tanácsadás mellett a hallgatói szolgáltatások fejlesztési koncepciója is megjelent. Az 1990-es évektől mind a tanácsadás, mind a szolgáltatásfejlesztés a legtöbb főiskolán és egyetemen meghonosodott és pozitiv módon járul hozzá a felsőoktatási intézmények működéséhez.

Magyarországon a felsőoktatási tanácsadás intézményes kereteinek kialakulása az 1990es években kezdődött. Az első szervezetek a hallgatók személyes pszichológiai tanácsadási igényeire reagálva jöttek létre, pszichológiát tanító tanárok kezdeményezésére. Budapesten az Eötvös Loránd Tudományegyetem Pszichológiai Diáktanácsadója, illetve a Semmelweiss Orvostudományi Egyetem hasonló szervezeti egysége, Debrecenben pedig a Kossuth Lajos Tudományegyetem "Négyszemközt" elnevezésű hallgatói tanácsadást folytató szervezete voltak az úttörők, amelyeket később sok más felsőoktatási intézmény is követett. Miután a hallgatói tanácsadók szükségességét törvényileg is lefektették, mára már az ország szinte minden felsőoktatási intézményében működik hasonló szolgáltató központ, amely a Hallgatói Önkormányzatoktól függetlenül, önálló szervezeti egységként funkcionál.

2000 táján a különböző felsőoktatási intézmények hallgatói tanácsadóiban felmerült az igény, hogy megosszák egymással eddigi tapasztalataikat, illetve hogy találkozókat szervezzenek, ahol együtt gondolkodva új ötletek merülhetnek fel a szolgáltatók müködésével kapcsolatban. Ezen igényre támaszkodva alakult meg a Felsőoktatási Tanácsadás Egyesület (FETA), amelynek megalakulása óta lehetőség nyilik arra, hogy a különböző felsőoktatási intézmények hallgatói tanácsadó szervei között meginduljon a diskurzus, egymás útkeresésére 
és eredményeire támaszkodva kiépüljön egy átfogó, intézményes keretek között müködő rendszer.

Kutatások bebizonyították, hogy a tanácsadó szolgáltatásban részesülő hallgatók általában nagyobb arányban szerzik meg a diplomát, mint azok, akik nem részesülnek ilyen szolgáltatásban, valamint kisebb a valószínűsége annak, hogy kimaradnak a föiskoláról tanulmányi okok miatt, ha úgy döntenek, hogy visszavonulnak. A pszichológiai tanácsadás két fő feladata: intervenció az aktuális problémák terén, illetve prevenció, a fennálló helyzetből fakadó lehetséges problémák megelőzése. Ebből adódóan a pszichológiai tanácsadás, mint intézmény a felsőoktatás valamennyi hallgatója számára tud hasznos és alkalmazható tanácsokkal szolgálni.

$\mathrm{Az}$ saját tanácsadói tevékenységem során felmerülő problémák három nagy csoportba sorolhatók, egyrészt a tanulással összefüggő kérdések, másrészt magánéleti problémák, harmadrészt pedig az identitáskeresés buktatói jelentek meg az egyes konzultációkon.

Az általános és középiskolai tanulási formáról való átállás egy önállóan kontrollált és nagyobb szabadságot biztosító tanulási módra nagy változást jelent az ember életében. A főiskolán a hallgatónak önállóan kell beosztania az idejét, nem jellemző a középiskolában megszokott tanár általi „kézen fogva vezetés", a rendszeres készülés és számonkérés, így könnyen megesik, hogy a hallgató kezéből kicsúszik az irányítás, és úgy érzi, hogy összecsapnak a feje fölött a hullámok. A tanácsadó feladata, hogy a hallgatót megpróbálja rávezetni a probléma tárgyilagos szemszögből való vizsgálatára, hogy együtt megtalálják a kitűzendő célt és az ehhez vezető lépéseket, valamint hogy a tanácsadó segítse a hallgatót a konkrét lépések megtételében.

Az előbbi általános probléma mellett több aktuális, időleges probléma is felmerülhet, amelyről úgy érzi a hallgató, hogy képtelen egyedül megoldani.
Az identitáskeresés legjellemzőbb, tanulással is összefüggő példája, hogy kételyek merülnek föl a hallgatóban, hogy vajon jól választott-e iskolát, szakmát, hogy vajon valóban érdekli-e őt a szak, amit választott. A tanácsadónak - ismét az objektivitás fegyverével - fel kell tárnia és tudatosítania a hallgatóban, hogy nem egyedül ő küszködik ezzel a problémával, hogy a korosztályának egy tipikus dilemmája foglalkoztatja őt is, ugyanakkor a támogatás és segítés légkörében éreznie kell a hallgatónak a tanácsadó bizalmát, és egyedi megoldást kell keresniük, természetesen együttes munkával.

A konzultációkon több probléma is felmerült az identitás kérdéskörében, amelyek az élet más területeivel vannak összefüggésben. Természetesen felmerül a kérdés, hogy a hallgatók miért nem egymással beszélik meg a problémáikat, hiszen hasonló cipőben járnak. A válasz a kérdésre a már sokat emlegetett objektivitás: tapasztalatot igénylő feladat kívül maradni és „rálátó“ szemszögből láttatni a problémát.

A magánéleti kérdések legjellemzőbb problémája a szülőkkel való konfliktus, az e helyzetben érzett tehetetlenséggel való megküzdés. $\mathrm{A}$ tanácsadó fontos feladata a konfliktuskezelés felnőtt módjára való rávezetés, ezáltal az élet más területein - nemritkán a főiskolán - felmerülő konfliktushelyzetek megoldására egy eszköz nyújtása, amely biztosítja a felnőtté válás egyik lépcsőjét.

Az eddig végzett tanácsadói munka tapasztalatai azt mutatják, hogy a szolgáltatás valóban keresletre talál, a főiskola hallgatói igénylik ezt a fajta személyes kontaktust. A hallgatói tanácsadás a főiskola minden hallgatójának szól, a pszichológiai tanácsadás megadja a lehetőséget mindenkinek, aki igénybe veszi, hogy egyenlő esélyekkel, a támogatottság érzésével, az akadályok leküzdésére megszerzett erővel vágjon neki a főiskolai éveknek.

Ahhoz azonban, hogy az egyenlő esélyeket biztosítsuk, szükség van egyrészt a hallgatóság 
felé folyó kétirányú zavartalan kommunikációra, másrészt az oktatók támogatására. Az oktatóknak lehetőségük van arra, hogy a hallgatók figyelmét felhívják a tanácsadásra, illetve ha úgy látják, hogy egy hallgatónak szüksége van pszichológus segítségére, akkor személyesen ajánlják ezt. A tanácsadás akkor tud jól működni, ha három pillérre támaszkodik: a tanácsadókra, akik megteremtik a segítség feltételeit; a hallgatókra, akik felismerik és megragadják ezt a lehetőséget; valamint az oktatókra, akik a tanácsadókhoz és a hallgatókhoz is kapcsolódva közvetítő szerepet töltenek be a két fél kommunikációjában.

A következőkben néhány konkrét problémát vehetünk szemügyre, amellyel a főiskola nappali tagozatos hallgatói fordultak a tanácsadó pszichológusokhoz. feltételek összehangolását, valamint a háttérfeltételek megteremtését, jobbá tételének elősegítését, a következő elemekre fókuszál.

Személyi feltételeknek nevezzük a tanulási folyamatban a hallgató

- személyes adottságait, képességeit,

- belső hangulati, érzelmi és motivációs állapotát,

- saját magáról kialakított képét, önértékelését, önbecsülését,

- vélekedését mindezekről és a tanulásról.

Környezeti feltételeknek nevezzük a tanulási folyamatban a hallgató

- anyagi lehetőségeit,

- esetleges munkahelyének viszonyulását a tanuláshoz,

- családjának viszonyulását a tanuláshoz,

\begin{tabular}{|l|l|l|}
\hline Általános probléma & Konkrét probléma & A tanácsadó feladata \\
\hline \multirow{4}{*}{ Családi problémák } & $\begin{array}{l}\text { Szülő elvesztése: hirtelen halál, } \\
\text { súlyos betegség, válás }\end{array}$ & Krízismegelőzés, gyászfeldolgozás \\
\cline { 2 - 3 } & $\begin{array}{l}\text { A kommunikáció sikertelensége, } \\
\text { érzelemszegénység }\end{array}$ & $\begin{array}{l}\text { Verbális és nem verbális kommunikáció elő- } \\
\text { segítése, összehangolása }\end{array}$ \\
\cline { 2 - 3 } & Anyagi problémák & Az önállóságra való buzdítás \\
\hline Tanulási nehézségek & Átállás egy új tanulási formára & $\begin{array}{l}\text { Az idő úirastrukturálásában nyújtott segit- } \\
\text { ség }\end{array}$ \\
\cline { 2 - 3 } & $\begin{array}{l}\text { Életformaváltás, szocializáció } \\
\text { egy idegen környezetben }\end{array}$ & $\begin{array}{l}\text { Új kapcsolatok kialakítása, régi kapcsolatok } \\
\text { megtartása, segítség a csoporthoz való iga- } \\
\text { zodásban }\end{array}$ \\
\cline { 2 - 3 } & Teljesitményszorongás & $\begin{array}{l}\text { Önértékelési zavarok leküzdése, a szorongás } \\
\text { feloldására módszerek keresése }\end{array}$ \\
\cline { 2 - 3 } & Motivációhiány & A megfelelő pálya felé történő orientáció \\
\hline Életszakasz - problémák & Identitáskeresés & $\begin{array}{l}\text { Kortárs élményekkel a „nincs egyedül” érzé- } \\
\text { sének erősitése }\end{array}$ \\
\cline { 2 - 3 } & Párkapcsolati gondok & $\begin{array}{l}\text { A túlzott közelség és az elszigetelödés közötti } \\
\text { egyensúly megtalálása }\end{array}$ \\
\hline
\end{tabular}

Ha a counselling általánosságban a tanulási feltételek megteremtését tűzi ki céljául, amely magában foglalja a személyi feltételek biztosítását, illetve a személyi és a fennálló környezeti
- -val más kapcsolatban lévők viszonyulását a tanuláshoz.

Háttérfeltételeknek nevezzük a hallgató

- fennálló családi kapcsolatait, 
- fennálló intim kapcsolatait,

- fennálló baráti, munkahelyi vagy laza társas kapcsolatait.

A tanulás elősegítése érdekében legfontosabbnak tűnik a hallgató személyi feltételeinek előmozdítása, ez azonban csak akkor sikerülhet, ha mind a környezeti, mind a háttérfeltételek optimális szintűek. Tehát abban az esetben, ha a környezeti és a háttérfeltételek biztosítottak, a counselling a személyi feltételekre összpontosul. Abban az esetben viszont, ha a környezeti és/vagy háttérfeltételek nem adottak, a counselling elsősorban ezekre irányul, majd e feltételek rendezésén keresztül a személyi feltételek biztosítására.

\subsection{A tanácsadásban résztvevő hallgatók pszichológiai jellemzői}

A counselling tevékenységhez elsősorban a tanácskérő életkorát kell figyelembe venni, mert az életkori sajátosságok, az egy adott életszakaszhoz kapcsolódó tipikus problémák ismerete megkönnyíti a tanácsadó munkáját.

A következő életszakaszokban lévő hallgatók kerülhetnek be a felsőoktatásba:

\begin{tabular}{|l|l|}
\hline \multicolumn{1}{|c|}{ Életszakasz } & $\begin{array}{l}\text { A hallgató számára fontos } \\
\text { kapcsolati rendszerek } \\
\text { (fontossági sorrendben) }\end{array}$ \\
\hline $\begin{array}{l}\text { Késői serdülőkor } \\
\text { (18-22 év) }\end{array}$ & $\begin{array}{l}\text { Csoportközösség } \\
\text { Iskola vagy munkahely } \\
\text { Család } \\
\text { Laza társas kapcsolatok }\end{array}$ \\
\hline $\begin{array}{l}\text { Korai felnőttkor } \\
\text { (23-30 év) }\end{array}$ & $\begin{array}{l}\text { Új család } \\
\text { Munkahely } \\
\text { Baráti kapcsolatok } \\
\text { Laza társas kapcsolatok }\end{array}$ \\
\hline $\begin{array}{l}\text { Átmenet az érett } \\
\text { felnőttkorba } \\
\text { (30-35 év) }\end{array}$ & $\begin{array}{l}\text { Család } \\
\text { Munkahely } \\
\text { Baráti kapcsolatok } \\
\text { Laza társas kapcsolatok }\end{array}$ \\
\hline
\end{tabular}

\subsubsection{A késői serdülőkor}

A késői serdülőkorban a 18-22 éves fiatalok legfontosabb fejlődésbeli feladata az önálló élet kialakítása, amelyben a pályaválasztási kísérlet fontos szerepet kap. Nem ritka azonban - mivel az identitáskeresés még nem zárult le - a nem megfelelő pályaorientáció, amelyet a későbbiekben korrigálni lehet. Az önálló élet másik kelléke az erkölcsi önállóság, amelyhez a korábbi szexuális intimitást felváltó szoros intim kapcsolatok kezdete nagyban hozzájárul. A 1822 évesek gondolkodását a relativitás jellemzi, annak a személetmódnak a kialakulása, hogy az emberek együttélését társas szerződések alapozzák meg.

A késői serdülőkor konkrét fejlődési feladatait és fejlődési kríziseit foglalja össze a következő táblázat.

\begin{tabular}{|l|l|}
\hline Anyagi függetlenség keresése & \\
\cline { 1 - 1 } $\begin{array}{l}\text { Önfelderités, } \\
\text { önismeret elmélyítése }\end{array}$ & \\
\cline { 1 - 1 } $\begin{array}{l}\text { Önálló döntések és következ- } \\
\text { ményeik megtapasztalása }\end{array}$ & $\begin{array}{c}\text { Egyéni } \\
\text { identitástudat } \\
\text { vagy } \\
\text { Intim kapcsolatok elmélyítése }\end{array}$ \\
\cline { 1 - 1 } $\begin{array}{l}\text { Többséghez való kiegyensú- } \\
\text { lyozott igazodás }\end{array}$ \\
\cline { 1 - 1 } Felelősségtudat kialakulása \\
\hline
\end{tabular}

\subsubsection{A korai felnőttkor}

A 23-30 éves korai felnőttkorban lévő fiatalok feladatai az új család és a munkahely köré csoportosulnak. A családi életvitel megszokása, a szülőszerep kipróbálása, illetve az életpálya kialakítása jelentenek újdonságot, valamint a két legfontosabb közeg, a család és a munkahely összeegyeztetése, amely egy új életstílus kialakítását vonja maga után. A családi kapcsolatokban az elkötelezettségre való képesség fejlődik. 
Az alábbi táblázatban a korai felnőttkor fejlődési feladatait és krízisét vehetjük szemügyre.

\begin{tabular}{|l|l|}
\hline $\begin{array}{l}\text { Családi pénzügyek } \\
\text { tervezésében való } \\
\text { jártasság megszerzése }\end{array}$ & $\begin{array}{l}\text { Képesség } \\
\text { a társadalmi } \\
\text { együttélésre, } \\
\text { bensőséges } \\
\text { kapcsolat } \\
\text { vagy } \\
\text { problémámák megoldása }\end{array}$ \\
\cline { 1 - 1 } $\begin{array}{l}\text { Szülői szerepkör } \\
\text { megismerése, elsajátítása }\end{array}$ & elidegenedés \\
\cline { 1 - 1 } $\begin{array}{l}\text { Szerepek különválása, } \\
\text { illetve integrációja }\end{array}$ & \\
\hline
\end{tabular}

\subsection{3. Átmenet az érett felnőttkorba}

A 30-35 éves kor egy átmeneti időszak, amely a korai felnőttkort és az érett felnőttkort köti össze. Ebben a korszakban jelentkezik az első számvetés az eddigi élettel, amely új lendületet ad a változtatáshoz. A családban a nagyobb gyerekkel kapcsolatban felmerülő problémák jelentenek egy eddig ismeretlen gondot, a munkával kapcsolatosan a hivatástudat kibontakozása figyelhető meg. A munkahelyen és a magánéletben egyaránt a fontos emberek jó véleményének kihívása fontos hajtóerő lesz.

A 30-35 éves kor fejlődési feladatait és krízisét látjuk az alábbi táblázatban.

\begin{tabular}{|l|c|}
\hline $\begin{array}{l}\text { Eddigi pálya } \\
\text { kiértékelése és döntéshozatal }\end{array}$ & \\
\hline $\begin{array}{l}\text { Eddigi kapcsolatok } \\
\text { kiértékelése és döntéshozatal }\end{array}$ & $\begin{array}{c}\text { Megújulás } \\
\text { vagy } \\
\text { rezignáció }\end{array}$ \\
\hline $\begin{array}{l}\text { Eddigi életstílus } \\
\text { kiértékelése és döntéshozatal }\end{array}$ & \\
\hline $\begin{array}{l}\text { Személyes segítő } \\
\text { kapcsolatok kialakítása }\end{array}$ & \\
\hline
\end{tabular}

\section{TANULÁSTÁMOgATÁS}

A tanácsadó konkrét feladatai közé mindenekelőtt az elérhetőség tartozik. A hallgatónak éreznie kell azt a biztonságot, hogy bármilyen problémával bármikor felkereshetia tanácsadót és számíthat a segítségére. Az elérhetőséget minden lehetséges formában biztosítani kell. A személyes beszélgetés, a telefonon történő beszélgetés, valamint az elektronikus levelezés mellett olyan kommunikációs lehetőségeket is számba kell venni, amelyek a tanácskérő számára lehetővé teszik az anonimitást. Ilyen lehetőség például a hagyományos levelezés, illetve a névtelenül eljuttatott írásos problémákra nyilvános válasz adása, amely természetesen a probléma általános leírására épül és csak a publikus részleteket tartalmazza, például egy erre a célra készített kiadványban eljuttatva a hallgatókhoz.

A tanácsadónak törekednie kell arra, hogy a bizalom légkörét megteremtse. Ehhez három feltétel teljesülése szükséges:

- A tanácsadó legyen őszinte. Önmagát adja, legyen áttetsző a tanácskérő előtt.

- A tanácsadó legyen elfogadó. Feltétel nélkül fogadja el és becsülje meg a tanácskérőt.

- A tanácsadó legyen empatikus. Érezze pontosan a tanácskérő adott pillanatban érzett érzéseit.

A tanácsadó feladatai a képzéshez kapcsolódóan három szakaszban értelmezhetők. A feladatok a képzés megkezdésekor, a kurzusok alatt és után a hallgató személyi, környezeti és háttérfeltételeinek felmérését, optimális szintre hozását, valamint szinten tartását foglalják magukban.

A tanácsadó feladatai a képzés kezdetén:

- a hallgató tanulási képességeinek, tanulási stílusának felmérése,

- a hallgató szükségleteinek felmérése,

- a hallgató környezeti feltételeinek tisztázása,

- a hallgatónak legmegfelelőbb képzési forma kiválasztása,

- a hallgató énképének, önbizalmának felmérése,

- segítség az időbeosztásban, a szemeszter megtervezésében. 
A tanácsadó feladatai a szemeszter során:

- a hallgató motiváltságának fenntartása,

- a hallgató önbizalmának erősitése,

- segítség a mindennapi tanulásban, a feladatok elvégzésében,

- segítség a felmerülő negatív érzések leküzdésében,

- alternatív tanulási módszerek ajánlása,

- segítség a hallgató környezeti és háttérfeltételeiben megjelenő negatívumok feldolgozásában. A tanácsadó feladatai a szemeszter végén:

- a tanulással és a vizsgával kapcsolatos félelmek eloszlatása,

- a hallgató „lelki” felkészítése a vizsgára,

- a vizsga közben fellépő stressz feldolgozása,

- a környezeti és háttérfeltételek vizsgahelyzetre gyakorolt hatásainak tudatosítása, feloldása.

\subsection{A tanácsadó feladatai a képzés kezdetén}

\subsubsection{A hallgató tanulási}

képességeinek, tanulási stílusának felmérése

A tanácsadó a bizalom légkörének megteremtése után célzott kérdéseket tesz fel, amelyek a hallgató tanulási stílusára vonatkoznak. A tanácsadónak törekednie kell arra, hogy a hallgatótól ne általánosságokat kérdezzen, hanem mindig megtörtént, konkrét szituációkat.

Néhány példa a kérdésekre:

- Mikor szokott tanulni (a nap mely szakában)?

- Idézze fel a legutóbbi helyzetet, amikor valamit megtanult. Akkor mely napszakban tanult?

- Úgy érzi, hogy ez a magának legmegfelelőbb napszak a tanulásra, vagy csak kényszerüségből választotta ezt?

- Egyszerre mekkora mennyiségű anyagot tud megtanulni?

- Legutóbb, amikor sokat kellett tanulnia, mennyit tudott egyszerre megtanulni?

- Mennyi idő után fárad el a tanulásban?

- Mit gondol, Önnek mely tanulási forma felel meg a leginkább?
- Mikor tud a leghatékonyabban tanulni, ha hallja az anyagot - mondjuk egy előadáson -, ha látja az anyagot leírva - mondjuk egy tankönyvben -, ha látja lerajzolva, ábrákkal tagolva, vagy ha hangosan elmondja magának?

- Milyen módszert használt legutóbb? (Olvasás, többszöri olvasás, felmondás, PQRST módszer.)

- Ha megtanul valamit, mennyi ideig emlékszik rá?

- Idézzen fel egy legutóbb megtanult rövidebb anyagot ( $p l$. egy verset)!

- Egyedül szeret tanulni vagy inkább társaságban?

- Ha többen tanulnak, jobban megérti az anyagot?

- Ha többen tanulnak, kikérdezik egymástól az anyagot vagy inkább beszélgetnek róla? Önnek melyik a hatékonyabb?

- Képes megtanulni úgy egy anyagot, hogy nem érti (képes bemagolni), vagy inkább törekszik a mélyebb megértésre?

- A középiskola elvégzése óta volt tanulási helyzetben?

- A munkahelyén előfordul, hogy rövid időn belül el kell sajátítania valamit?

- Mikor könnyebb az elsajátítás, ha készségszintű dologról van szó (pl. a számítógép-kezelés), vagy ha elméletiről (pl. egy prezentációra történő felkészülés)?

\subsubsection{A hallgató szükségleteinek felmérése}

A szükségletek a cselekvések okait szolgáltató belső hajtóerők. Az ember minden cselekvése motivált, a tanácsadó feladata a hallgató tanulással kapcsolatos motivációinak feltárása.

Példák a kérdésekre:

- Miért döntött úgy, hogy továbbtanul?

- Ki döntött a továbbtanulás mellett, Ön, a családja, a munkahelye,...?

Ha az derül ki, hogy a hallgató kényszerűségből tanul tovább, a távolabbi céljai elérését kell hangsúlyoznia a tanácsadónak.

- Mi a célja a diploma megszerzésével? 
- Milyen tervei vannak a diploma megszerzése után?

Ha nincsenek távolabbi céljai, akkor tudatosítani lehet az igazi okot, ami miatt a főiskolára jött, pl. a szülőknek való megfelelés, vagy jobb híján a munkanélküliség elkerülése.

Ha saját döntése a továbbtanulás, szúkíthető a kör:

- Miért főiskolát választott?

- Miért a Szolnoki Főiskolát választotta?

- Miért az adott tagozatot választotta?

Külső, kényszerítő körülmények említése esetén a távolabbi célok elérésére lehet kérdezni. Belülről fakadó okok említése jó alapot ad a motivált tanulás fenntartására.

\subsubsection{A hallgató}

környezeti feltételeinek tisztázása

A hallgató környezeti feltételei a körülötte élő emberek viszonyulását jelzik, a hallgató tanulásával kapcsolatban.

A hallgató életkorának függvényében a kapcsolati rendszerek változóak lehetnek. Általánosságban a család, a munkahely, az intim kapcsolatok, a baráti és a lazább társas kötelékek jelentik a hallgató számára a véleményét vagy a hozzáállását befolyásolni tudó közeget.

A kapcsolati rendszerekre vonatkozó kérdéseket a formálisabb kapcsolatoktól kiindulva kezdi a tanácsadó, és fokozatosan halad az intimebb kapcsolatok felé. Abban az esetben, ha a hallgató részéról ellenállás mutatkozik, a beszélgetést nem szerencsés erőltetni.

Példák a kérdésekre:

- A munkahelyi környezete hogy viszonyul ahhoz, hogy Ön elkezdett tanulni?

- Mit szólnak a főnökei? (Esetleg ők küldték?)

- A közvetlen munkatársai milyen véleménynyel vannak erről?

- Ön mit gondol, össze tudja majd egyeztetni a munkáját és a tanulást? Lesz ideje mindkettőre?

- Milyen következményekkel jár majd a munkahelyén, ha megszerzi a diplomát?
- Mások is tanulnak a munkatársai közül?

- Milyen viszonyban van a munkatársaival?

- Sok barátja van a munkahelyén?

- A barátai mit szólnak ahhoz, hogy Ön tanul?

- Mit gondol, a diploma megszerzése eredményez majd valami változást a baráti kapcsolataiban?

- A családja hogy viszonyul ahhoz, hogy Ön tanul?

- Támogatják Önt a tanulásban?

- Mit gondol, okoz majd bármilyen változást az életükben az, hogy Ön tanul? (PI. új időrend kialakítása.)

- Partnerek abban a családja tagjai, hogy együtt oldják meg az esetlegesen felmerülő problémákat?

- Mit szól a felesége/férje/barátja/barátnője?

- Együtt döntötték el, hogy tanulni fog?

- Megbeszélték előre az esetleges változásokat az életükben?

\subsubsection{A hallgatónak}

legmegfelelőbb képzési forma kiválasztása

A legmegfelelőbb képzési forma kiválasztásakor figyelembe kell venni a következőket, a megadott sorrendben:

- a hallgató anyagi körülményeit,

- a hallgató formális kapcsolatainak viszonyulását,

- a szükségleteit,

- az informális kapcsolatainak a viszonyulását,

- a tanulási stílusát.

A sorrend a hallgató belső és külső tényezőinek megváltoztatási lehetőségén alapul.

\subsubsection{A hallgató énképének, önbizalmának felmérése}

A hallgató énképe, speciálisan a tanulással kapcsolatban saját magáról kialakított képe meghatározza a tanuláshoz való hozzáállását.

A hallgató saját magába vetett hite, a saját képességeiről való tudása, az önbizalma meg- 
alapozzák a tanulás sikerét. Az önbizalom magabiztosságot ad a hallgatónak, amely segít a tanulással kapcsolatos kezdeti félelmek, illetve a vizsgahelyzetben fellépő szorongás csillapításában.

Az önbizalom alapja az önismeret, az önmagunkról való tudás, amely nem feltétlenül azonos mások rólunk alkotott képével. Az ember személyiségének van olyan része, amelyet csak ő ismer, és mások számára láthatatlan, illetve van olyan része, amelyet mások ismernek, de ő nem. Természetesen van olyan rész is, amelyet mások is és önmaga is ismer, van azonban olyan is, amelyet senki sem ismer.

A counselling tevékenység során a tanácsadó „képviseli” az általános másikat, vagyis az ő feladata, hogy a hallgatónak visszajelzést adjon egy külső szempontból. Ez a beszélgetések során úgy nyilvánul meg, hogy a tanácsadó „visszatükrözi” a hallgató gondolatait, érzéseit, mondatait, nem verbális megnyilvánulásait.

Például: „Jól értem, hogy ezzel azt akarja mondani, hogy ..."

Így a hallgatónak lehetősége van arra, hogy egy külső szemszögből is vizsgálja a saját a viselkedését, és megtalálja az eltéréseket a saját gondolatai, érzései, illetve ezek kifejeződései és a mások által látott, neki tulajdonított gondolatok, érzések között.

Az önbizalom felmérésére alkalmazhatók különböző papír-ceruza tesztek, amelyeket a hallgatónak egyedül kell kitöltenie, majd a tanácsadó kiértékeli, és együtt megbeszélik az eredményeket. A tesztek eredménye alapot adhat a tanulással kapcsolatos önértékelési pontok beazonosítására és megbeszélésére.

\subsection{Segítség az időbeosztásban, a szemeszter megtervezésében}

A felsőoktatásban nincs óráról órára rendszeres számonkérés, amely a hallgató részéről sokkal nagyobb fokú önállóságot követel, mint a kö- zépiskolai tanulás. A tanácsadónak ezért mindig készenlétben kell állnia, folyamatosan megerősítenie a hallgatóban, hogy szüksége van a tanulásra (felhasználva a szükségletfelmérés eredményeit), valamint éreztetnie kell a támogatást, amelynek egyébként a tudata is átsegíti a hallgatót a bizonytalanságokon.

\subsection{A tanácsadó feladatai a szemeszter során}

\section{2. 1. A hallgató motiváltságának fenntartása}

A képzés kezdetekor megismert motivációk fenntartása kell törekednie a hallgatónak a képzés közben is, amelyben a tanácsadó a segítségére lehet.

Fontos a hallgatóval való rendszeres találkozás, a motivációk rendszeres megbeszélése. A hallgató által kitűzött célok megvalósítási lehetőségei, illetve a már megvalósult célok összevetése az eredeti elképzelésekkel. Fontos feltárni azokat a tényezőket, amelyek eltérítették az eredeti elképzelésektől a cél megvalósítását.

Ezen folyamatokhoz segítséget nyújthat, ha minden félév vagy év végén a hallgató a tanácsadó segítségével elvégzi az adott időszakra vonatkozó SWOT analízist.

\subsection{A hallgató önbizalmának erősítése}

A képzés kezdetén felmért önbizalom szintjének megtartásában, illetve erősítésében az elért eredmények, például sikeres vizsgák, vagy sikeres félévzárás, esetleg egy-egy otthoni feladat megoldása adhat alapot.

Sok esetben előfordul, hogy a hallgató az évfolyamtársaihoz méri magát, és teljesítményét nem látja olyan jónak, mint a többiekét. A tanácsadó feladata, hogy tudatosítsa a hallgatóban, hogy minden ember más, másképp tanul, más képességekkel rendelkezik, és az élet nem minden területén nyújt egyforma teljesítményt. 
Az életben, a munkahelyen és a családban lehetőség van arra, hogy mindenki kiválassza a magának megfelelő munkaritmust, a képességeihez és az érdeklődéseihez idomuló területeket. Ez a szabadság egy iskolai közegben nem jellemző, hiszen a hallgatónak egy elöre összeállított tanrendet kell követnie, amelyben kevés választási lehetőség van. Emiatt fordul elő, hogy néhányan nem érzik a sikerességet, mert olyan kurzusokon kötelező részt venniük, amelyek nem pontosan illeszkednek a sajátos, egyéni stílusukhoz. A tanácsadónak erre fel kell hívnia a hallgató figyelmét és inkább azokra a sikerekre irányítani azt, amelyek a hallgatónak valóban fontosak.

\subsection{Segítség a mindennapi tanulásban, a feladatok elvégzésében}

A tanácsadó segítséget nyújthat a tanulással kapcsolatos nehézségek, például a rossz időbeosztásból fakadó kellemetlenségek leküzdésében. Ha a hallgató ezt igényeli, akkor közösen megbeszélhetnek egy újfajta időrendet, és szóbeli megállapodást kötnek, hogy a hallgató valamennyi, előre meghatározott ideig követi és betartja azt. A megbeszélt idő leteltével a tanácsadóval megbeszélik a folyamat sikerességét, illetve a változtatásra szoruló pontokat.

Ebben az esetben a tanácsadó külső kontrollálóként van jelen, betartatja az előzetesen kialkudott szabályokat, majd a folyamat végén elismerésben részesíti a hallgatót, vagy rossz teljesítmény esetén rávilágít a hallgató által elkövetett hibákra. Ez utóbbit határozottan kell végezni a tanácsadónak azzal a kinyilvánított szándékkal, hogy a hallgató előrejutását könnyítse. Ehhez a tanácsadónak az én-üzenetek adnak segítséget, amelyek arra szolgálnak, hogy a hallgatóban kellemetlen érzések nélkül változást indítsanak be.
Példák a rossz és jó hiba-rávilágításra:

\begin{tabular}{|c|c|}
\hline $\begin{array}{l}\text { Nem megfelelő, } \\
\text { kellemetlen } \\
\text { érzéseket keltő } \\
\text { hibáztatás }\end{array}$ & $\begin{array}{l}\text { Problémára és megoldására } \\
\text { irányuló, nem hibáztató } \\
\text { én-üzenetek }\end{array}$ \\
\hline $\begin{array}{l}\text { A tegnapi } \\
\text { megbeszélt } \\
\text { feladatot nem } \\
\text { oldotta meg. } \\
\text { Ön a hibás, } \\
\text { amiért ma nem } \\
\text { sikerült időben } \\
\text { megérkeznie az } \\
\text { oktatásra. }\end{array}$ & $\begin{array}{l}\text { Úgy érzem, hogy a tegnapi } \\
\text { feladatot nem sikerült } \\
\text { jól megoldania, ezért ma } \\
\text { elkésett az oktatásról. Ön } \\
\text { is látja mostmár, hogy } \\
\text { legközelebb a főnökével } \\
\text { egy nappal előbb érdemes } \\
\text { megbeszélni, hogy engedje el } \\
\text { Önt hamarabb a munkából. }\end{array}$ \\
\hline $\begin{array}{l}\text { Hogy gondolta, } \\
\text { hogy sikerülni fog } \\
\text { a vizsgája? Hiszen } \\
\text { csak egy napot } \\
\text { készült rá! }\end{array}$ & $\begin{array}{l}\text { Úgy látom, hogy hasznos } \\
\text { lenne újra megbeszélnünk, } \\
\text { hogy hogyan osztjuk be a } \\
\text { vizsgaidőszakot. Mit gondol, } \\
\text { milyen körülmények között } \\
\text { lehetett volna a mai vizsgája } \\
\text { sikeres? }\end{array}$ \\
\hline $\begin{array}{l}\text { El kellett volna } \\
\text { mondania, hogy } \\
\text { mi a problémája, } \\
\text { akkor talán } \\
\text { tudtam volna } \\
\text { segíteni. }\end{array}$ & $\begin{array}{l}\text { Azt gondolom, hogy } \\
\text { bármilyen problémáját } \\
\text { megoszthatja velem, } \\
\text { remélem, Ön is így látja. } \\
\text { Szerintem együtt könnyebb } \\
\text { megoldást találni, szeretném, } \\
\text { ha tudná, hogy mindig } \\
\text { számíthat a segítségemre. }\end{array}$ \\
\hline
\end{tabular}

\section{2. 4. Segítség a felmerülő}

negatív érzések leküzdésében

Gyakran előfordul, hogy a hallgató a tanulást úgy éli meg, mint egy elzárkózást, elszigetelődést, a külvilágtól való elhatárolódást, amely kellemetlen érzéseket kelthet.

Személyiségpszichológiai szempontból megvizsgálva biológiai alapokra vezethető vissza az egyén extravertált, illetve introvertált személyisége. Az extravertált hallgatóra jellemző a társasági élet, a kifelé forduló magatartás, a tanulásra vonatkoztatva inkább szeret csoportosan tanulni. Az introvertált személyiségű hall- 
gató pedig befelé forduló, nem annyira kedveli a társaságot, inkább az egyedüllétet, tanulni is egyedül szeret.

Az extra- és introverzió személyiségdimenzió biológiai alapja az éberségi szintet szabályozó idegrendszeri mechanizmusban rejlik. Az arousalrendszer felelös minden emberben egy általános éberségi szintért, amelyben eltérés található az extra-, illetve introvertált személyiségekben. (Természetesen nincsen extravertált és introvertált személyiségtípus, hanem egyénenként változó az extra- és introverzió mértéke.)

A kutatások alapján az általános éberségi szint és az extraverzió összefüggésében éppen ellenkező eredményeket találunk, mint amit az ember józanésszel először gondolna. Magától értetődőnek tűnik, hogy az extravertált, kifelé forduló személyiség magasabb éberségi szinttel rendelkezik, az introvertált, befelé forduló pedig alacsonyabbal. Ezt az első hallásra logikus összefüggést cáfolta meg a kutatási eredmény, amely szerint éppen fordított az összefüggés: az extravertáltakra az alacsonyabb éberségi szint, az introvertáltakra a magasabb éberségi szint jellemző.

Ezt az eredményt fiziológiai bizonyítékok támasztják alá, tehát számszerūen mérhető az arousalrendszer által biztosított éberségi szint. A számszerü eredmény mellett a viselkedésből is vonhatunk le következtetéseket, de ha kizárólag a viselkedést használjuk az éberségi szint meghatározására, akkor az előbb említett tévedéshez jutunk.

A magyarázata ennek a paradox helyzetnek könnyen megérthető. Az extravertált személyiség, aki alacsony éberségi szinttel rendelkezik, a viselkedésével kompenzálja ezt. Folyamatosan szüksége van a külvilágból különböző ingerekre, hogy fenn tudja tartani az alacsony éberségi szintjét. Ha az éberségi szint túl alacsony lesz, az elalvást eredményez.

$A z$ introvertált személyiségnek, akire a magasabb éberségi szint jellemző, nincs szüksége viselkedésbeli kompenzációra, a külvilág ingereire az éberségi szintje fenntartásához, viszont ha túl sok külső inger éri, akkor a túl magas éberségi szintet feszültségnek fogja érezni az egyén, ami nyilvánvalóan nem kellemes érzés.

Tehát az extravertált személyiség akkor érzi jól magát, ha a külső ingerek segítségével megtartja az éberégi szintjét. Az introvertált személyiség pedig akkor, ha a külső ingerek nem zavarják meg, nem emelik meg túlzottan az éberségi szintjét. Ebből adódik a két személyiség különbsége, amely a társas együttlét kedveléséhez, illetve elutasításához vezet.

A tanulás következtében érzett elszigetelődés kellemetlensége tehát valószínűleg az extravertált személyiségeknek okoz gondot, akik egyébként a tárgyi, illetve társas környezetüket úgy szervezik meg maguk körül, hogy azok segítségével tulajdonképpen - egyszerűen fogalmazva - ne aludjanak el. Ezek az egyének, amikor egyedül kénytelenek valamit tenni, kellemetlenül érzik magukat.

\subsection{Alternatív tanulási módszerek ajánlása}

Az előzőekből adódóan a tanácsadó feladata, hogy körülbelül meghatározza a hallgató személyiségét az extraverzió szempontjából, és ha azt látja, hogy a hallgató szenved a magánytól, és ezért nem megy a tanulás, akkor a csoportos tanulási módszert ajánlja.

Egy másik ok, amely alátámasztja a csoportos tanulás hatékonyságát, a „több szem többet lát” mondásból következik. Az anyag együttes tesztelése, ellenőrzése lehetőséget ad arra, hogy a hallgatók megbeszéljék egymással azokat az anyagrészeket, amiket nem értenek, így az anyagrész mélyebb feldolgozása következik be, amelyet az együttgondolkodás tesz lehetővé.

3.2. 6. Segítség a hallgató környezeti és háttérfeltételeiben megjelenő negatívumok feldolgozásában

Nagyon gyakran előfordul, hogy a hallgató a családi vagy a munkahelyi problémái miatt nem tud 
koncentrálni, azokat képtelen kikapcsolni, kizárni a gondolkodásából a tanulás közben ezért a tanulás hatékonysága erőteljesen lecsökken.

Ebben az esetben a tanácsadóval történő probléma-megbeszélés, az, hogy egyáltalán van valaki, akivel megbeszélheti a problémáit, sokat segithet a kellemetlen lelkiállapot leküzdésében.

\subsection{A tanácsadó feladatai a szemeszter végén}

\subsubsection{A tanulással és}

a vizsgával kapcsolatos félelmek eloszlatása

A tanácsadó feladata, hogy tudatosítsa a hallgatóban, hogy a jól megtanult, kellőképpen feldolgozott anyagrész elővezetésére a vizsgahelyzet feszültsége kedvező hatással van. Egészen egyszerü példa, hogy az ember általában egy jól begyakorolt dolgot - például leírni a nevét a feszült helyzetekben is meg tud tenni.

A gond akkor van, ha egy kevéssé megtanult anyagrészről kell a hallgatónak számot adnia, mert ebben az esetben a vizsgahelyzettel járó feszültség nem elősegíti, hanem éppen gátolja az anyagrész jó felidézését. Ezért mindenképpen az anyag megfelelő elsajátítására kell törekedni.

\subsubsection{A hallgató felkészítése a vizsgára}

A tanácsadó feladata, hogy hangsúlyozza a vizsgahelyzet könnyítő, facilitáló hatását a jól elsajátított anyagrészre, illetve ennek ellenkezőjét a kevésbé mélyen feldolgozott anyagrészre. A vizsgahelyzetben érzett feszültség leküzdésére a szimulált vizsgahelyzet adhat lehetőséget, amikor a hallgató egy ugyanolyan szituációban vesz részt, kipróbálhatja a tudását, megtapasztalhatja a vizsgahelyzet hatását a teljesítményére.

A szimulált vizsgahelyzettel biztosítjuk a hallgató számára, hogy a valódi vizsga szituációját nem érzi annyira idegennek, így az idegenségérzésből fakadó feszültség kiküszöbölhető.

A szimulált vizsgahelyzet biztosít a hallgatónak egy tanulási folyamatot - hiszen az ember esetén egy próba is tanulást eredményez -, amelynek segítségével, az elsajátított viselkedéssel a valódi vizsgahelyzetben megkövetelt viselkedés a hallgató számára már nem tűnik járatlan útnak.

\subsubsection{A vizsga közben \\ fellépő stressz feldolgozása}

Nagyon fontos a vizsgahelyzet, a vizsga közbeni viselkedés utólagos megbeszélése, ezzel ráveszi a tanácsadó a hallgatót saját viselkedésének külső szemmel történő megfigyelésére.

A megfigyelést a szimulált vizsgahelyzet megbeszélésével ajánlott kezdeni, a viselkedéstől függően a tanácsadóval együtt kidolgozható egy viselkedéskészlet, amelyet a valódi vizsgán a hallgató megpróbál követni.

A valódi vizsga megbeszélésekor az előzetesen kialkudott viselkedéskészlet megvalósítását lehet vizsgálni, a következményeit, illetve a befolyásoló tényezőket, amelyek esetleg nem engedték egyegy megbeszélt viselkedés megvalósítását.

A vizsgán fellépő stressz levezetéséhez szintén különböző viselkedéseket lehet gyüjteni, nagyon fontos azonban, hogy a tanácsadó ebben a helyzetben ne direktív módon adjon tanácsot, hanem tulajdonképpen egy társas alku szülessen a hallgató és a tanácsadó között.

3.3.4. A környezeti és háttérfeltételek vizsgahelyzetre gyakorolt hatásainak tudatositása, feloldása

A családi és munkahelyi problémák éppúgy hátrányosan befolyásolhatják a vizsgán nyújtott teljesítményt, mint a tanulási folyamat hatékonyságát.

A környezeti és a háttérfeltételekben fellépő zavaró hatásokról beszélni kell, rávezetni a hallgatót arra, hogy ezek hogyan befolyásolják a teljesítményét, megoldási lehetőségeket keresni, amelyek nem a vizsgahelyzetre, hanem a háttérfeltételekre irányulnak. 
Felhasznált irodalom

[1.] Tari Annamária (2013) Ki a fontos: Én vagy Én? Budapest, Tericum Kiadó Kft.

[2.] Almási Kitti - Bagdy Emőke - Beata Bishop - Böjte Csaba - F. Várkonyi Zsuzsa - Orosz Katalin - Pál Ferenc - Popper Péter - Ranschburg Jenő - Szendi Gábor - Vekerdy Tamás (2013) A lélek dolgai. A Nyitott Akadémia válogatott előadásai önfejlesztésről, kapcsolatokról és konfliktuskezelésről. Budapest, Kulcslyuk Kiadó Kft.

[3.] Járó Katalin (szerk.) (2013) Felelősség és siker. A tranzakcióanalízis mint döntésmenedzselés. Budapest, Háttér Kiadó Kft.

[4.] Hans Jürgen Eysenck - Michael W. Eysenck (2001) Elmevadászat. A megfigyelt lélek. Budapest, Kairosz Könyvkiadó Kft.

[5.] Pál Ferenc (2012) A szorongástól az önbecsülésig. Budapest, Kulcslyuk Kiadó Kft. 